\title{
LEGISLACIÓN DE DERECHO ADMINISTRATIVO
}

\author{
Fernando GONZÁLEZ BotIJA \\ Departamento de Derecho Administrativo \\ Facultad de Derecho. \\ Universidad Complutense de Madrid \\ dp143@ucm.es
}

- Real Decreto-ley 10/2017, de 9 de junio, por el que se adoptan medidas urgentes para paliar los efectos producidos por la sequía en determinadas cuencas hidrográficas y se modifica el texto refundido de la Ley de Aguas, aprobado por Real Decreto Legislativo 1/2001, de 20 de julio (BOE, núm. 138, de 10 de junio de 2017).

- Real Decreto-ley 9/2017, de 26 de mayo, por el que se transponen directivas de la Unión Europea en los ámbitos financiero, mercantil y sanitario, y sobre el desplazamiento de trabajadores ( $B O E$, núm. 126, de 10 de mayo de 2017).

- Ley $1 / 2017$, de 18 de abril, sobre restitución de bienes culturales que hayan salido de forma ilegal del territorio español o de otro Estado miembro de la Unión Europea, por la que se incorpora al ordenamiento español la Directiva 2014/60/UE del Parlamento Europeo y del Consejo, de 15 de mayo de 2014 (BOE, núm. 93, de 19 de abril de 2017).

- Resolución de 16 de marzo de 2017, del Congreso de los Diputados, por la que se ordena la publicación del Acuerdo de derogación del Real Decreto-ley 4/2017, de 24 de febrero, por el que se modifica el régimen de los trabajadores para la prestación del servicio portuario de manipulación de mercancías dando cumplimiento a la Sentencia del Tribunal de Justicia de la Unión Europea de 11 de diciembre de 2014, recaída en el asunto C-576/13 (procedimiento de infracción 2009/4052) (BOE, núm. 71, de 24 de marzo de 2017).

- Real Decreto-ley 4/2017, de 24 de febrero, por el que se modifica el régimen de los trabajadores para la prestación del servicio portuario de manipulación de mercancías dando cumplimiento a la Sentencia del Tribunal de Justicia de la Unión Europea de 11 de diciembre 
de 2014, recaída en el asunto C-576/13 (procedimiento de infracción 2009/4052) (BOE, núm. 48, de 25 de febrero de 2017).

- Resolución de 31 de enero de 2017, del Congreso de los Diputados, por la que se ordena la publicación del Acuerdo de convalidación del Real Decreto-ley 7/2016, de 23 de diciembre, por el que se regula el mecanismo de financiación del coste del bono social y otras medidas de protección al consumidor vulnerable de energía eléctrica (BOE, núm. 32, de 7 de febrero de 2017).

- Ley $1 / 2017$, de 3 de enero, del control del potencial vitícola en la Comunidad Autónoma de La Rioja (BOE, núm. 17, de 20 de enero de 2017). 